\title{
Design of a Locally Water Based Drilling Fluid
}

Received: 23 November 2017

Accepted: $9^{\text {th }}$ May 2018

Published: $20^{\text {th }}$ September 2018

https://doi.org/10.47545/etrj.2018.3.2.043

\section{"Oyedeko K.F.K and Dawodu O. O.}

\author{
Lagos State University, Nigeria \\ * \\ e-mail: kfkoyedeko@yahoo.com
}

\begin{abstract}
This study is based on formulating drilling fluid from local bentonite clay. The local clay was prepared with drilling mud additives such as starch, barite, and potash to improve the properties of the local clay as drilling fluid. The properties of the drilling fluid produced were compared with the API specifications. Some of the properties that met the specification are the PH, moisture content while the viscosity of the drilling fluid produced from the local clay was close to the API specification. The locally made drilling fluid could be a substitute for imported one which could eventually contribute to the development of country solid minerals.
\end{abstract}

Keywords: Additives, Clay, Rheological properties, Viscosity

\section{INTRODUCTION}

Drilling fluid is a critical component in safe drilling in either gas or oil exploration. It is generally a viscous, heavy fluid designed to perform a variety of functions. It serves the purpose of assisting in maintaining a maximum drilling rate which is compatible with safety. It also helps to remove drill cutting from the bottom of the hole, the face of the drilling bit and carry them out of the borehole. Drilling fluid supports and protects the wall of the hole against caving or collapse by the pressure of the fluid column. Moreover, it keeps the drill cuttings in suspension when circulation is stopped or when replacing a worn bit. It helps in cooling the bit [14]. Also enable satisfactory electric log be obtained. This demand that the fluid has certain properties of electrical conductivity or resistivity [14]. Optimized drilling fluid leads to successful open hole gravel pack completion installation in unconsolidated reservoir [5].

Several factors need to be considered when designing drilling fluids. For example, formation permeability determines filtration characteristics. Range of temperature or water-sensitive formations determine the type of polymer and type of drilling fluids needed. Polymer compatibility with drilling fluids is important to achieve good suspension, rheology, and filtration control to ensure good hole cleaning and less formation damage. Important considerations in designing drilling fluids include rheological properties to provide good carrying capacity and minimum filtration control [1]. Polymeric additives used to increase viscosity the fluid must be chosen carefully on the basis of the brine used to achieve the required density. Chemical compatibility of various components must be determined to avoid rheological property deterioration [1,5]. Interest in silicatebased drilling fluids which have been used in a number of areas over the past 50 years, less important from the 1950s until the mid-1990s [6,8]. However, renewed interest has led to their use in a number of drilling fluid applications in various regions $[7,8,13]$.

There are basically three broad categories of drilling fluids nowadays. These are: Pneumatic fluids, which use compressed air or gas, foam and aerated muds. Water Based drilling fluids, which use water or brine as the base fluids. Non-aqueous base fluids called oil based drilling fluids, or synthetic based fluids[10].

Water based drilling fluids: These are mixtures of active solids like bentonite water and other additive chemicals with the water acting as the continuous phase. The active solid is the dispersed phase providing the main gel structure to control the fluid properties. These chemical additives which are in various proportions control the $\mathrm{pH}$, viscosity, weight, fluid loss, etc. of the fluid.

Barite is used to increase mud weight; CMC (Carboxy-methyl-Cellulose) a polymer is used to control fluid loss; Lignite can be used to control mud viscosity; Also, there are Loss Control Materials (LCM) to prevent and control the total loss of whole mud into the formation. 
Oil based muds: These are similar in composition as Water based muds except that the continuous phase is oil [14].

Synthetic based muds: To reduce cost and minimize pollution, new synthetic oils are now being developed and used to make synthetic based muds (SBMs). The SBMs are classified according to molecular structure of the synthetic fluids which can be esters, ethers, etc. They have drilling and operational properties similar to oilbased mud (OBMs) but have the advance of being more "environmentally friendly" [2,14,11,].

Designing drilling fluids depends heavily on the selection of the suitable size of weighing material which equally acts as bridging materials. The use of bridging materials is important to minimize fines migration and improve hole stability.

Requirements for water-based drilling fluids include physical stability, cuttings transport, lubricity, and formation damage $[1,8]$.

The main rheological properties are apparent viscosity, plastic viscosity, gel strength, yield, flow behavior index (n) and consistency (k). Therefore optimum combinations of these properties are required. These properties are adjustable to suit specific requirements whereas the mud density is largely dependent on the formation pore pressure.

This study is conceived to develop drilling fluid from local bentonite clay from two different locations (Ife Edun Abon, Osun State and Bayeku, Ikorodu Lagos State), and characterize them. With the problem of foreign exchange in the country, it is worthwhile to explore the large deposit of clay minerals that exist locally. This will reduce the importation of drilling mud and subsequently boost the country's foreign reserve which appreciates the local currency. It is also expected to compliment the Federal government policy on Local Content and Solid Minerals.

\section{MATERIALS AND METHODS}

All additives used in this work are typical materials for drilling fluids such as Starch, Local clay, Barite, Potash, Distilled water were obtained locally.

The starch used was obtained from Epe local market; it was dried, ground and sieved to a size of $75 \mu \mathrm{m}$. The barite used is from Azara in Nassarawa state which have already been partially beneficiated. The potash was also dried and ground in preparation for mixing.

Other chemical reagents include solid sodium polyphosphates, solid sodium hydroxide and solid sodium carbonates. The analyses consist of the following; Physical analysis: Odors, texture, color, visual composition, dry substance

Chemical analysis: Plastic viscosity, viscosity, yield point, density, swell volume, moisture content, residue weight.

\subsection{Sample preparation}

Crusher - This was used to crush the clay into smaller pieces.

Weighing balances - To determine the weight of materials and mud respectively.

Stirrer - to homogenize the mixture.

Viscometer- to measure the viscosity at various shear rates. The brand name of the viscometer is NDJ-8S Digital viscometer.

Oven - This was used for drying.

Beakers - This was used for mixing the samples. The volume of the beaker is $200 \mathrm{ml}$

Sieve - This was used to sieve the clay to its finest particle size. It has a mesh size of $75 \mu \mathrm{m}$.

$\mathrm{PH}$ meter - This was used to measure the PH of the mud

Mud Density -'This is measured normally with a mud balance.

Rheological properties: Apparent viscosity, plastic viscosity, yield point, gel strength, flow behaviour index (n) and consistency $(\mathrm{k})$. Properties are derived from measurements carried out with viscometers. 
The clay was defined as: Clay from Ife Edun Abon, Osun State as clay I and clay from Bayeku, Ikorodu Lagos State as clay II.

The clay sample was washed to remove organic particles and subsequently dried prior to grinding and pulverization. The clay was crushed, sieved in a sieve of mesh size $75 \mu \mathrm{m}$ and with the aid of wrist action shaker.

\subsection{Experimental Procedures}

The materials were mixed in such variable ratios that the individual effect of each of the constituents in the mixture could be observed easily, thus determining the function of each component in the sample.

Plastic viscosity and yield point measurement: A direct indicating rotational viscometer is used to measure the viscosity at different shear rates. The instrument has a torsion spring-loaded bob which gives a dial reading proportional to torque and analogous to the shear stress. The speed of rotation (rpm) is analogous to the shear rate. The viscometer indicates the shear stress as a 'dial unit' at a given shear rate (one dial unit equal about 1 $\mathrm{lb} / 100 \mathrm{sq} \mathrm{ft})$. The dial reading is determined as:

$\theta=Y P+P V\left(\frac{\omega}{300}\right)$

Where $\theta$ is the dial reading, YP is the yield point, PV is plastic viscosity, $\omega$ is rotational speed (rpm) [4].

The drilling mud formulation from each of the two clay samples was poured into a viscometer cup-of the digital rotational viscometer NDJ-8S and the readings were taken at $600 \mathrm{rpm}$ and $300 \mathrm{rpm}$ respectively, according to the API recommended practice and recorded.

The PV in centipoise was calculated from the 600rpm dial reading $\left(\theta_{600}\right)$ minus $300 \mathrm{rpm}$ dial reading $\left(\theta_{300}\right)$ The $\mathrm{YP}$ in $1 \mathrm{lb} / 100 \mathrm{sq} \mathrm{ft}$ was calculated from the 300rpm dial minus the PV [10].

The values for plastic viscosity, yield point and their ratio were recorded for each of the sample.

Residue: In this case, $40 \mathrm{~g}$ of clay was weighed out.

1. The clay sample weighed was added to approximately $175 \mathrm{ml}$ of water containing about $8 \mathrm{~g}$ of sodium hexametaphosphate,

2. The suspension was stirred for about 30 minutes,

3. The sample was then transferred to the sieve of a mesh size of $75 \mu \mathrm{m}$.

4. The residue was transferred from the sieve to an evaporating dish,

5 The residue was dried in an oven to a constant weight and this was recorded for the two clay.

\subsection{Analytical Methods}

Density Determination of Mud Composition: Each of the samples prepared were transferred into calibrated beakers through which the volume was determined, after this the mixtures were then weighed on a weighing balance. The values for the volume and mass derived were then recorded and used to determine the density of the samples.

Swell Index determination: Two different samples were prepared. The first was with $20 \mathrm{~g}$ clay was mixed with $10 \mathrm{~g}$ starch only, while the second was $20 \mathrm{~g}$ clay mixed with $10 \mathrm{~g}$ starch and $15 \mathrm{~g}$ Sodium Hydroxide. These mixtures were subsequently dissolved in $70 \mathrm{ml}$ of water, it was then aged for 24 hours, and the final mass and swell index of clay mixture were determined and recorded using swell index as defined in equation (2).

Swell Index $=\frac{\left(V_{d}-V_{k}\right)}{V_{k}} x 100 \%$

Where $\mathrm{V}_{\mathrm{d}}$ is the volume of clay with starch in water, $\mathrm{V}_{\mathrm{k}}$ is volume of clay, starch and sodium hydroxide in water [9].

Moisture: $40 \mathrm{~g}$ of the clay sample was weighed into an evaporating dish. The sample was then dried in an oven to a constant weight, after which it was cooled to room temperature. The evaporating dish containing the dry clay was then reweighed and the values recorded. 


\section{RESULTS AND DISCUSSIONS}

\subsection{Results.}

The Results obtained from samples prepared from the two clay according to experimental design are given in Tables 1-6.

Table 1A: DENSITY OF CLAY I MUD SAMPLES

\begin{tabular}{llllllll}
\hline Sample & $\begin{array}{l}\text { Water } \\
(\mathrm{ml})\end{array}$ & $\begin{array}{l}\text { Starch } \\
(\mathrm{g})\end{array}$ & Clay $(\mathrm{g})$ & $\begin{array}{l}\mathrm{Na}_{2} \mathrm{CO}_{3} \\
(\mathrm{~g})\end{array}$ & $\begin{array}{l}\text { Barite } \\
(\mathrm{g})\end{array}$ & $\begin{array}{l}\mathrm{NaOH} \\
(\mathrm{g})\end{array}$ & $\begin{array}{l}\text { Density } \\
\left(\mathrm{g} / \mathrm{m}^{3}\right)\end{array}$ \\
\hline $\mathrm{A}$ & 75 & 10 & 20 & 3 & 15 & 1 & 2.24 \\
$\mathrm{~B}$ & 75 & 15 & 20 & 3 & 15 & 1 & 2.32 \\
$\mathrm{C}$ & 75 & 10 & 20 & 3 & 15 & - & 2.2 \\
$\mathrm{D}$ & 75 & 15 & 20 & 3 & 20 & 1 & 2.34 \\
\hline
\end{tabular}

Table 1B: DENSITY OF CLAY II MUD SAMPLES

\begin{tabular}{llllllll}
\hline Sample & $\begin{array}{l}\text { Water } \\
(\mathrm{ml})\end{array}$ & $\begin{array}{l}\text { Starch } \\
(\mathrm{g})\end{array}$ & $\begin{array}{l}\text { Clay } \\
(\mathrm{g})\end{array}$ & $\begin{array}{l}\mathrm{Na}_{2} \mathrm{CO}_{3} \\
(\mathrm{~g})\end{array}$ & $\begin{array}{l}\text { Barite } \\
(\mathrm{g})\end{array}$ & $\begin{array}{l}\mathrm{NaOH} \\
(\mathrm{g})\end{array}$ & $\begin{array}{l}\text { Density } \\
\left(\mathrm{g} / \mathrm{m}^{3}\right)\end{array}$ \\
\hline $\mathrm{A}$ & 75 & 10 & 20 & 3 & 15 & 1 & 2.23 \\
$\mathrm{~B}$ & 75 & 15 & 20 & 3 & 15 & 1 & 2.32 \\
$\mathrm{C}$ & 75 & 10 & 20 & 3 & 15 & - & 2.21 \\
$\mathrm{D}$ & 75 & 15 & 20 & 3 & 20 & 1 & 2.35 \\
\hline
\end{tabular}

Table 2A: SWELL INDEX OF CLAY I MUD SAMPLES

\begin{tabular}{lllllll}
\hline Sample & Water $(\mathrm{ml})$ & Starch $(\mathrm{g})$ & Clay $(\mathrm{g})$ & $\mathrm{NaOH}(\mathrm{g})$ & Mass $(\mathrm{g})$ & Swell Index \\
\hline A & 75 & 10 & 20 & - & 103 & 3.19 \\
B & 75 & 10 & 20 & 5 & 198 & 3.41 \\
\hline
\end{tabular}

Table 2B: SWELL INDEX OF CLAY II MUD SAMPLES

\begin{tabular}{lllllll}
\hline Sample & Water $(\mathrm{ml})$ & Starch $(\mathrm{g})$ & Clay $(\mathrm{g})$ & $\mathrm{NaOH}(\mathrm{g})$ & Mass $(\mathrm{g})$ & Swell Index \\
\hline A & 75 & 10 & 20 & - & 105.6 & 3.76 \\
$\mathrm{~B}$ & 75 & 10 & 20 & 5 & 200.2 & 3.88 \\
\hline
\end{tabular}

Table 3A: VISCOMETER READINGS AT SHEAR RATES 600rpm AND 300rpm FOR CLAY I

\begin{tabular}{lllll}
\hline Viscometer speed (rpm) & \multicolumn{4}{c}{ Shear rate $\left(\mathrm{sec}^{-1}\right)$} \\
\hline \multirow{3}{*}{300} & A & B & C & D \\
600 & 100.6 & 133.3 & 78 & 100.4 \\
& 117.4 & 151.3 & 90.4 & 127.3 \\
\hline
\end{tabular}

Table 3B: VISCOMETER READINGS AT SHEAR RATES 600rpm AND 300rpm FOR CLAY II

\begin{tabular}{lllll}
\hline Viscometer speed (rpm) & \multicolumn{4}{c}{ Shear rate $\left(\mathrm{sec}^{-1}\right)$} \\
\hline \multirow{3}{*}{300} & A & B & C & D \\
600 & 91.7 & 122.1 & 63.4 & 99.2 \\
\hline
\end{tabular}


Table 4A: VISCOSITY, YIELD POINT AND THEIR RATIO FOR THE CLAY I MUD SAMPLES

\begin{tabular}{lllll}
\hline & $\mathrm{A}$ & $\mathrm{B}$ & $\mathrm{C}$ & $\mathrm{D}$ \\
\hline PLASTIC VISCOSITY (cps) & 16.8 & 18 & 12.9 & 26.8 \\
YIELD POINT (lb/100sq ft) & 83.8 & 115.3 & 65.4 & 73.6 \\
RATIO & 4.98 & 6.4 & 5.04 & 2.2 \\
\hline
\end{tabular}

Table 4B: VISCOSITY, YIELD POINT AND THEIR RATIO FOR THE CLAY II MUD SAMPLES

\begin{tabular}{lllll}
\hline & A & B & C & D \\
\hline PLASTIC VISCOSITY ( cps) & 17.5 & 21.3 & 18.1 & 24.8 \\
YIELD POINT (lb/100 sq ft) & 74.2 & 100.8 & 45.3 & 74.4 \\
RATIO & 4.24 & 4.73 & 2.5 & 3 \\
\hline
\end{tabular}

Table 5: PH MEASUREMENT

\begin{tabular}{lll}
\hline SAMPLE & CLAY I & CLAY II \\
\hline A & 10.64 & 10.23 \\
B & 10.14 & 9.73 \\
C & 8.2 & 8.09 \\
\hline
\end{tabular}

Table 6: MOISTURE WEIGHT and RESIDUE WEIGHT

\begin{tabular}{lll}
\hline & MOISTURE & RESIDUE \\
& WEIGHT \% & WEIGHT\% \\
\hline CLAY I & 5.12 & 14.5 \\
CLAY II & 6.25 & 18.2 \\
\hline
\end{tabular}

\subsection{Discussion of Results}

The drilling fluid properties measured included plastic viscosity, yield point, pH. density, swell index. The Mud compositions were made in such a way that the effect of each constituent of the mud mixture could be studied, like the effect of Barite on density, starch on density, and clay on viscosity, sodium silicate and sodium hydroxide on swell volume and also the effect of water on clay rheology. Good drilling muds will posses pseudo plastic nature when subjected to shear and flow.

Density Variation with Barite in Samples: From samples A, B and D for the two clay samples in Table 1 there is increase in mud theoretical density from sample A B and sample D when the barite content were varied from $15 \mathrm{~g}$ to $20 \mathrm{~g}$. It was observed that the Barite which increases mud weight shows that the higher the value of Barite in sample $\mathrm{D}$, the weightier the mixture and increase the density. Also, it is observed that the values of experimental densities fall within the API specified range for drilling mud.

Density Variation with clay and starch in Samples: From samples A and B from Table 1 for the two clay, there is an increase in mud theoretical density from sample A and sample D when the clay content were varied with starch from $10 \mathrm{~g}$ to $15 \mathrm{~g}$ Variation in experimental density were also observed with highest in sample B. This shows that the starch which acts as a thickener makes the sample B with higher starch content thicker than sample A. And the higher the value of starch added the more thickener the mixture and the higher the density.

Swell Index: It was discovered that the swell index of the local bentonitic clay is poor. Therefore, Clay and starch were treated with Sodium Hydroxide in sample A and sample B for both clay according to experimental 
design as shown in the Table 2. It was observed in sample B with sodium hydroxide which is a clay extender makes the sample to swell and increase the swell index local clay to several times the original size.

Plastic viscosity values, yield point-plastic viscosity ratio: Viscosity increases with increase in quantity of starch contained in samples as shown in Table 4. Starch is an organic polymer used as filtration control additives and contributed to the thickening of the samples.

From Table 3, the shear rates at the viscometer speed of 600rpm of the samples are in better agreement with the API specification than that viscometer speed of 300rpm. However, the values of $17 \mathrm{cp}$ for plastic viscosity, and 4 for yield point-plastic viscosity ratio from Table 4 are only close meeting the API specification

pH Determination: It was observed that the presence of sodium hydroxide increase the $\mathrm{pH}$ value of the local clay. It acts as an alkalinity source. And the higher the value of $\mathrm{NaOH}$ added the higher the $\mathrm{pH}$ value, which falls within the range 9.5-10.5 for clay II, as specified in API recommended practice. Starch was used as a viscosity-building ability, and as a the source of both viscosity and fluid-loss control. It is subject to bacterial degradation and must be used with a preservative except in saturated salt water or at a $\mathrm{pH}$ above 11.5. this is in agreement with the literature [12].

\section{CONCLUSION}

Based on the experimental results and observations, It can be concluded that the clay obtained from Ife, Edun Abon and Bayeku, Ikorodu Lagos State can be used in producing drilling fluid because the mud samples for the two local clay have good rheology properties and meet some of the API specification which serve as a criteria in the production of drilling mud, but there is still room for improvement especially for specific drilling to meet all the requirement set by the API.

It is recommended that government should provide funds for full exploration of local bentonite clay and barites deposits in the country so as to develop the solid minerals in the country and help conserve our foreign exchange.

\section{REFERENCES}

[1] Abdullah, S.A, Abdullah, A, Abdulaziz, B, Qmar, A and Ali, A. (2014). Innovative Manganese Tetroxide/Cacl2 Water-Based Drilling fluids for HP/HT Wells. SPE Latin American and Caribbean Petroleum Engineering Conference, Venezuela. Journal of Petroleum Technology. Pp 102-105.

[2] Anuradee, W, Kathi, C.,Ahmad, B, Dennis,.C, Ronalld,B, Akachai, K, Michael, P,, Khairui,A and Abshar, M (2014). Ultra HP/HT Drilling Fluid Design for Frontier Deep Gas Exploration in South Malay Basin. Journal of Petroleum Technology. Pp 98-100.

[3] Amanullah, M. (2003). A Novel Method to Evaluate the formation Damage Potential of Drilling fluids. SPE Asia Pacific Oil and Gas Conference and Exhibition. Journal of Petroleum Technology. pp. 51-52.

[4] Baker, H. (2006). Drilling Fluids Reference Manual, Baker Hughes Drilling Fluids, USA.

[5] Cobianco, S., Pitoni,E., Ricci,P.N and Galli,.M.(2003). Optimized Drill-in Fluid for an Openhole GravelPack Completion. SPE European Formation Damage Conference. Hague. Journal of Petroleum Technology. pp. 55-56.

[6] Darley, H.C.H.., Gray, George, R., (1998). Composition and properties of Drilling and Completion Fluids, $5^{\text {th }}$ Edition, pg 38.

[7] D'Alessandro, Fulberto.(2001). An inhibitor system for drilling active clays. World Oil. Pg E.39

[8] Doug, W. Estes,W., Taryn,F and Harry, D. (2003). Drilling fluid Cementing Improvements reduce per ft drilling costs by ten percent. World Oil. pp 39-47.

[9] Er Jithesh (2016). Determine free swell index. Civil engineering test 
[10] IADC Manual (2014). International Association of Drilling Contractors. Techstreet, USA

[11] Mads, R., Erik, A., Steven, M and Renate, M.(2014). Clay-Free invert fluid in High-Temperature well provides consistent Low ECD profile. Journal of Petroleum Technology. pp. 95-97.

[12] Max R. A. and Martin V. S. (1974). Drilling fluids technology, Exxon Company, U.S.A.

[13] Rawlyk, Dave: McDonald, Michael. (2001). Potassium Silicate Based Drilling Fluids: An environmentally Friendly Drilling Fluids Providing Higher Rate of Penetrations. CADE/CAODC Drilling Conference, Calgary, Alberta Canada.

[14] Shell manual, (1983) Shell petroleum hand book-compile by staff of Royal Dutch shell 1983 Amsterdam, New York, Oxford. 